\title{
FEBRUARY 1972
}

TWELFTH YEAR - No. 131

\section{international review of the red cross}

\section{GENEVA}

INTERNATIONAL COMMITTEE OF THE RED CROSS FOUNDED IN 1863 


\section{INTERNATIONAL COMMITTEE OF THE RED CROSS}

MARCEL A. NAVILLE, President (member since 1967)

JEAN PICTET, Doctor of Laws, Chairman of the Legal Commission, Vice-President (1967)

HARALD HUBER, Doctor of Laws, Federal Court Judge, Vice-President (1969)

PAUL RUEGGER, Ambassador, President of the ICRC from 1948 to 1955 (1948)

GUILLAUME BORDIER, Certificated Engineer E.P.F., M.B.A. Harvard, Banker (1955)

HANS BACHMANN, Doctor of Laws, Winterthur Stadtrat (1958)

JACQUES FREYMOND, Doctor of Literature, Director of the Graduate Institute of International Studies, Professor at the University of Geneva (1959)

DIETRICH SCHINDLER, Doctor of Laws, Professor at the University of Zurich (1961)

MARJORIE DUVILLARD, Nurse (1961)

MAX PETITPIERRE, Doctor of Laws, former President of the Swiss Confederation (1961)

ADOLPHE GRAEDEL, member of the Swiss National Council from 1951 to 1963, former Secretary-General of the International Metal Workers Federation (1965)

DENISE BINDSCHEDLER-ROBERT, Doctor of Laws, Professor at the Graduate Institute of International Studies (1967)

JACQUES F. DE ROUGEMONT, Doctor of Medicine (1967)

ROGER GALLOPIN, Doctor of Laws, former Director-General (1967)

WALDEMAR JUCKER, Doctor of Laws, Secretary, Union syndicale suisse (1967)

VICTOR H. UMBRICHT, Doctor of Laws, Managing Director (1970)

PIERRE MICHELI (1971)

Honorary members: Mr. JACQUES CHENEVIEERE, Honorary Vice-President;

Miss LUCIE ODIER, Honorary Vice President; Messrs. CARL J. BURCKHARDT, PAUL CARRY, Mrs. MARGUERITE GAUTIER-VAN BERCHEM, Messrs. SAMUEL A. GONARD, EDOUARD de HALLER, PAUL LOGOZ, RODOLFO OLGIATI, FREDERIC SIORDET, ALFREDO VANNOTTI, ADOLF VISCHER.

Directorate: Mr. JEAN-LOUIS LE FORT, Secretary-General.

Mr. RAYMOND COURVOISIER, Special Assistant to the President and Director of Operations.

Mr. CLAUDE PILLOUD, Director, Department of Principles and Law. 


\title{
INTERNATIONAL REVIEW OF THE RED CROSS
}

\author{
FEBRUARY 1972 - No. 131
}

CONTENTS

\section{INTERNATIONAL. COMMITTEE OF THE RED CROSS}

IN THE RED CROSS WORLD

MISCELLANEOUS

BOOKS AND REVIEWS
J. Freymond : International Red Cross and

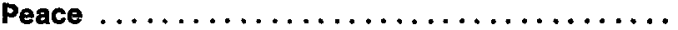
I. Domanska : Red Cross and the Problems of Environment

Conference of Red Cross Experts on the Reaffirmation and Development of International Humanitarian Law Applicable in Armed Conflicts (Circular No. 485 to the Central Committees)...

For the Benefit of the Indo-Pakistan Conflict

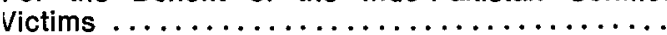

External Activities :

Khmer Republic - Republic of Vietnam - Zaire Middle East - Yemen Arab Republic .........

In Geneva :

Participation in the Geneva Conventions .....

Teaching of International Humanitarian Law ....

Norway ........................ 104

New Look for two Red Cross Magazines ...... 106

L'Institut de la Vie .................. 107

International Children's Centre ........... 111

Voluntary Organizations and Development .... 113 
FRENCH EDITION

OF THE REVIEW

\section{SUPPLEMENTS \\ TO THE REVIEW}

\section{SPANISH}

GERMAN

INTERNATIONAL

REVIEW OF

THE RED CROSS
The French edition of this Review is issued every month under the title of Revue internationale de la Croix-Rouge. It is, in principle, identical with the English edition and may be obtained under the same conditions.

H. Beer : La solidaridad Cruz Roja.

H. Beer : Die Solidarität des Roten Kreuzes (I) - Wie organisiert das IKRK seine Hilfsaktionen?

The International Review is published each month by the International Committee of the Red Cross

7, avenue de la Paix, 1211 Geneva I, Switzerland Postal Cheque No. 121767

Annual subscription: Sw. fr. 30.- $(\$ 8)$

Single copies $\mathrm{SW}$. fr. 3.- $(\$ 0.80)$

Editor: J.-G. LOSSIER

The International Committee of the Red Cross assumes responsibility only for material over its own signature. 